\title{
VALIDITAS PEMERIKSAAN KADAR HEMOGLOBIN MENGGUNAKAN METODE HB METER PADA REMAJA PUTRI DI MAN WONOSARI
}

\author{
Noor Hidayat, Sunarti \\ Fakultas Kesehatan Masyarakat, Universitas Ahmad Dahlan, Yogyakarta \\ Email: inart2020@yahoo.com
}

\begin{abstract}
Background: Anemia is still a nutritional problem in worldwide, especially in developing countries. Anemia is a medical condition which the number of red blood cells or hemoglobin less than $12 \mathrm{gram} / 100 \mathrm{ml}$. Determination to know anemia can be performed by laboratory test for examine the levels of hemoglobin. The level of hemoglobin test is one of the routine blood tests are needed to diagnose a disease. Many methods are used for examine hemoglobin levels, including methods tallquist, sahli, kupersulfat and cyanmethemoglobine. There is more practical hemoglobin levels test tool which used $\mathrm{Hb}$ meter. Gold standard used for checking hemoglobin levels are cyanmethemoglobine method.

Method: This research was a descriptive study which used laboratory test. The samples in this research were teenage girl class III in MAN Wonosari.

Result: The sensitivity velues is based on the results was $45.45 \%$, while the specificity values was $64.61 \%$. False positive values was $35.58 \%$, while the false negative velue was $54.54 \%$.

Conclusion: Sensitivity and specificity velues on this research this showed had result is not good.
\end{abstract}

Keyword: Hb meter, sensitivity, anemia, teenage girl, specificity

\begin{abstract}
Abstrak
Latar Belakang: Anemia masih menjadi salah satu permasalahan gizi di dunia terutama di negara berkembang. Anemia merupakan suatu kondisi medis dengan jumlah sel darah merah atau hemoglobin kurang dari $12 \mathrm{gram} / 100 \mathrm{ml}$. Penentuan untuk mengetahui anemia dapat dilakukan dengan pemeriksaan laboratorium yaitu dengan pemeriksaan kadar hemoglobin. Pemeriksaan kadar hemoglobin termasuk salah satu pemeriksaan darah rutin yang dibutuhkan untuk mendiagnosis suatu penyakit. Banyak metode yang digunakan untuk pemeriksaan kadar hemoglobin, diantaranya metode tallquist, sahli, kupersulfat dan cyanmethemoglobine. Akan tetapi baru-baru ini terdapat alat pemeriksaan kadar hemoglobin yang lebih praktis yaitu dengan metode $\mathrm{Hb}$ meter. Gold standard dari beberapa metode tersebut yang digunakan untuk pemeriksaan kadar hemoglobin adalah metode cyanmethemoglobine.

Metode: Jenis penelitian yang digunakan adalah deskriptif dengan uji laboratorium. Sampel pada penelitian ini adalah remaja putri kelas III di MAN Wonosari.

Hasil: Nilai sensitivitas berdasarkan perhitungan diperoleh hasilnya sebesar $45,45 \%$, sedangkan nilai spesifisitasnya sebesar $64,61 \%$. Nilai positif palsu diperoleh sebesar $35,58 \%$, sedangkan untuk negatif palsu sebesar $54,54 \%$.

Kesimpulan: nilai sensitivitas dan spesifisitas pada penelitian ini menunjukkan hasil yang kurang baik.
\end{abstract}

Kata Kunci: Hb meter, sensitivitas, anemia, remaja putri, spesifisitas

\section{Pendahuluan}

Anemia masih menjadi salah satu permasalahan gizi di dunia terutama di negara berkembang. Data WHO tahun 2008, diketahui penduduk dunia yang menderita anemia sebanyak 1,62 miliar orang dengan prevalensi sebesar $24,8 \%{ }^{1}$

Validitas Pemeriksaan Kadar Hemoglobin menggunakan Metode HB Meter .... (Noor Hidayat) 
Anemia banyak diderita oleh wanita hamil dengan prevalensi sebesar 55,9\% dan remaja sebesar $30-55 \%$ yang banyak terdapat di negara berkembang, salah satunya Indonesia. ${ }^{2}$ Anemia merupakan suatu kondisi medis dengan jumlah sel darah merah atau hemoglobin kurang dari normal yaitu 12 gram $/ 100 \mathrm{ml}^{3}{ }^{3}$ Kondisi ini berdampak terhadap fungsi kognitif dan memori, serta menurunkan kapasitas kerja sehingga dapat menurunkan konsentrasi dan prestasi sekolah. ${ }^{4}$

Penentuan untuk mengetahui anemia dapat dilakukan dengan pemeriksaan laboratorium yaitu dengan pemeriksaan kadar hemoglobin. Pemeriksaan kadar hemoglobin termasuk salah satu pemeriksaan darah rutin yang dibutuhkan untuk mendiagnosis suatu penyakit. Kegunaan dari pemeriksaan hemoglobin ini adalah untuk mengetahui ada tidaknya gangguan kesehatan pada pasien, misalnya kekurangan hemoglobin yang biasa disebut anemia. ${ }^{5}$

Banyak metode yang digunakan untuk pemeriksaan kadar hemoglobin, diantaranya metode tallquist, sahli, kupersulfat dan cyanmethemoglobine. Baru-baru ini terdapat alat pemeriksaan kadar hemoglobin yang lebih praktis dengan metode $\mathrm{Hb}$ meter. Pemeriksaan dengan menggunakan metode $\mathrm{Hb}$ meter sangat praktis, hasil yang didapatkan cepat dan mudah digunakan tanpa harus tenaga terlatih. ${ }^{6}$ Gold standard dari beberapa metode tersebut yang digunakan untuk pemeriksaan kadar hemoglobin adalah metode cyanmethemoglobine. ${ }^{7}$

Penelitian ini bertujuan untuk mengetahui berapa besar validitas pemeriksaan kadar hemoglobin menggunakan metode $\mathrm{Hb}$ meter pada remaja putri di MAN Wonosari.

\section{Metode Penelitian}

Penelitian ini merupakan jenis penelitian deskriptif dengan uji laboratorium. Penelitian deskriptif adalah penelitian yang bertujuan menggambarkan secara sistematik dan karakteristik mengenai populasi. ${ }^{8}$ Sampel dalam penelitian ini adalah remaja putri kelas III di MAN 1 Wonosari sebanyak 112 orang.

\section{Hasil Penelitian dan Pembahasan}

\section{A. Hasil Penelitian}

\section{1) Deskripsi Lokasi Penelitian}

Penelitian ini dilaksanakan di Madrasah Aliyah Negeri Wonosari. MAN Wonosari ini terletak di jalan Sunan Ampel no. 68 Desa Kepek, Kecamatan Wonosari Kabupaten Gunungkidul DIY, telephone (0274) 391377. Jumlah total keseluruhan murid MAN wonosari sebanyak 478 orang, yang terdiri dari remaja putra 145 orang dan remaja putri 333 orang. 
2) Karakterisitik Responden

Tabel 1. Karakteristik Responden Penelitian

\begin{tabular}{|c|c|c|}
\hline Variabel & Jumlah & Persentase \\
\hline \multicolumn{3}{|l|}{ Pekerjaan Orangtua } \\
\hline PNS & 12 & $15,8 \%$ \\
\hline Buruh & 17 & $22,4 \%$ \\
\hline Petani & 25 & $32,9 \%$ \\
\hline Wiraswasta & 17 & $22,4 \%$ \\
\hline Pedagang & 1 & $1,3 \%$ \\
\hline Pensiunan & 2 & $2,6 \%$ \\
\hline Perangkat desa & 1 & $1,3 \%$ \\
\hline TNI AD & 1 & $1,3 \%$ \\
\hline \multicolumn{3}{|l|}{ Umur } \\
\hline 15 tahun & 18 & $23,7 \%$ \\
\hline 16 tahun & 43 & $56,6 \%$ \\
\hline 17 tahun & 15 & $19,7 \%$ \\
\hline \multicolumn{3}{|l|}{ Hb meter } \\
\hline Anemia & 28 & $36,8 \%$ \\
\hline Tidak Anemia & 48 & $63,2 \%$ \\
\hline \multicolumn{3}{|l|}{ Cyanmethemoglobine } \\
\hline Anemia & 11 & $14,5 \%$ \\
\hline Tidak Anemia & 65 & $85,5 \%$ \\
\hline
\end{tabular}

Berdasarkan Tabel 1 hasil penelitian terhadap 76 orang remaja putri, dengan umur minimal pada penelitian ini 15 tahun dan umur maksimal adalah 17 tahun. Mayoritas pekerjaan orang tua responden adalah petani yaitu sebanyak 25 orang $(32,9 \%)$, remaja putri yang menderita anemia yang ditentukan dengan menggunakan metode $\mathrm{Hb}$ meter sebanyak 28 orang $(36,8 \%)$ sedangkan menggunakan metode cyanmethemoglobine sebanyak 11 orang $(14,5 \%)$ menderita anemia.

3) Analisis Data

Tabel 2. Nilai Validitas Pemeriksaan Hemoglobin Menggunakan Metode $\mathrm{Hb}$ meter di MAN Wonosari tahun 2014

\begin{tabular}{lccc}
\hline \multirow{2}{*}{ Metode Hb meter } & \multicolumn{2}{c}{$\begin{array}{c}\text { Metode } \\
\text { cyanmethemoglobine }\end{array}$} & \multirow{2}{*}{ Total } \\
\cline { 2 - 3 } & Anemia & Tidak Anemia & \\
\hline Anemia & 5 & 23 & 28 \\
Tidak Anemia & 6 & 42 & 48 \\
Total & 11 & 65 & 76 \\
\hline
\end{tabular}

Berdasarkan Tabel 2, maka dapat dihitung nilai sensitivitas, spesifisitas, negatif palsu dan positif palsu.

$$
\begin{aligned}
& \text { Sensitivitas }=\frac{a}{a+c} \times 100 \%=\frac{5}{11} \times 100 \%=45,45 \% \\
& \text { Spesifisitas }=\frac{d}{b+d} \times 100 \%=\frac{42}{65} \times 100 \%=64,61 \% \\
& \text { Negatif Palsu }=\frac{c}{a+c} \times 100 \%=\frac{6}{11} \times 100 \%=54,54 \% \\
& \text { Positif Palsu }=\frac{b}{b+d} \times 100 \%=\frac{23}{65} \times 100 \%=35,58 \%
\end{aligned}
$$


Nilai sensitivitas berdasarkan perhitungan diperoleh hasilnya sebesar $45,45 \%$, sedangkan nilai spesifisitasnya sebesar $64,61 \%$. Nilai positif palsu diperoleh sebesar $35,58 \%$, sedangkan untuk negatif palsu sebesar $54,54 \%$.

\section{B. Pembahasan}

Subjek dalam penelitian ini adalah remaja putri, dimana sebagian besar berusia 16 tahun (56,6\%). Masa remaja merupakan periode pertumbuhan anak-anak menuju proses kematangan manusia dewasa. Pada periode ini terjadi perubahan fisik, biologis, dan psikologis. Perubahan fisik yang terjadi akan mempengaruhi status kesehatan dan nutrisinya. Ketidakseimbangan antara asupan zat gizi dan kebutuhannya akan menimbulkan masalah gizi, baik berupa masalah gizi lebih maupun gizi kurang. ${ }^{9}$

Remaja putri merupakan salah satu kelompok rawan untuk menderita anemia. Remaja mempunyai kebutuhan nutrisi yang spesial, karena pada saat tersebut terjadi pertumbuhan yang pesat, maka kebutuhan akan zat besi pada remaja juga meningkat. Zat besi dibutuhkan oleh tubuh untuk membentuk mioglobin dalam jaringan otot yang baru. Zat besi lebih banyak dibutuhkan oleh remaja putri karena remaja putri mengalami haid (menstruasi) setiap bulan, di mana kehilangan zat besi $\pm 1.3 \mathrm{mg}$ per hari, sehingga kebutuhan zat besi lebih banyak dari pada remaja pria. Selain itu juga remaja putri biasanya ingin tampil langsing, sehingga membatasi asupan makanan yang mengandung zat besi. ${ }^{4}$

1) Sensitivitas pemeriksaan kadar hemoglobin menggunakan metode $\mathrm{Hb}$ meter pada remaja putri di MAN 1 Wonosari

Berdasarkan hasil pemeriksaan kadar hemoglobin menggunakan metode $\mathrm{Hb}$ meter dengan standarisasi metode cyanmethemoglobine yang merupakan baku emas (gold standard) untuk menentukan seseorang menderita anemia, nilai sensitivitas yang diperoleh sebesar $45,45 \%$, yang berarti hanya $45,45 \%$ diantara penderita anemia yang dapat dideteksi oleh alat ini. Hasil perhitungan tersebut menunjukkan bahwa metode $\mathrm{Hb}$ meter memiliki sensitivitas yang kurang baik. Menurut kriteria Dinas Kesehatan suatu alat diagnostik dikatakan memiliki sensitivitas yang baik jika nilainya $\geq 85 \% .{ }^{10}$ Penggunaan $\mathrm{Hb}$ meter yang kurang sensitif menandakan bahwa alat ini kurang baik dalam mengidentifikasi seseorang benar-benar sakit, sehingga alat ini tidak dianjurkan digunakan sebagai alat tes diagnostik untuk menentukan seseorang menderita anemia.

Berdasarkan penelitian yang telah dilakukan oleh Sulistiawati (2011) penyebab nilai sensitivitas kurang baik karena metode $\mathrm{Hb}$ meter memiliki beberapa kelemahan diantaranya alat bekerja tidak stabil atau alat tidak berfungsi secara normal atau alat tidak bekerja dengan baik karena alat yang kotor, alat bekerja tidak teliti, tidak peka. ${ }^{11}$ Walaupun uji ini mudah dan cepat dilakukan, tetapi tidak cukup baik untuk digunakan sebagai uji diagnostik rutin dikarenakan nilai sensitivitasnya yang rendah.

2) Spesifisitas pemeriksaan kadar hemoglobin menggunakan metode $\mathrm{Hb}$ meter pada remaja putri di MAN 1 Wonosari

Berdasarkan hasil pemeriksaan kadar hemoglobin menggunakan metode $\mathrm{Hb}$ meter dengan standarisasi metode cyanmethemoglobine yang merupakan baku emas (gold standard) untuk menentukan seseorang menderita anemia, nilai spesifisitas yang diperoleh sebesar $64,61 \%$, hasil 
perhitungan tersebut menunjukkan bahwa metode $\mathrm{Hb}$ meter memiliki spesifisitas yang kurang baik. Menurut Nugrahaeni (2011) menyatakan bahwa idealnya suatu alat uji yang berfungsi sangat baik seharusnya mempunyai spesifisitas yang cukup tinggi yaitu mendekati nilai $100 \%{ }^{12}$ Metode $\mathrm{Hb}$ meter yang memiliki spesifisitas yang kurang artinya alat ini dalam mendeteksi seseorang sehat atau tidak menderita anemia kurang baik.

Berdasarkan teori Morton (2008) mengatakan bahwa sebuah uji diagnostik terjadinya peningkatan spesifisitas akan menyebabkan terjadinya penurunan sensitivitas. ${ }^{13}$ Teori tersebut sejalan dengan penelitian yang telah dilakukan dimana hasil perhitungan dari spesifisitas sebesar $64,61 \%$ dan hasil perhitungan dari sensitivitas sebesar $45,45 \%$.

\section{3) Positif palsu pemeriksaan kadar hemoglobin menggunakan metode} $\mathrm{Hb}$ meter pada remaja putri di MAN 1 Wonosari

Berdasarkan hasil pemeriksaan kadar hemoglobin menggunakan metode $\mathrm{Hb}$ meter dengan standarisasi metode cyanmethemoglobine yang merupakan baku emas (gold standard) untuk menentukan seseorang menderita anemia, nilai positif palsu yang diperoleh sebesar 35,58\%. Positif palsu merupakan pelengkap dari nilai spesifisitas. Positif palsu sangat perlu untuk diketahui dalam sebuah uji karena untuk memperlihatkan bahwa seseorang menderita penyakit, tetapi sebenarnya tidak menderita suatu penyakit. Selain itu, positif palsu perlu diketahui agar dalam sebuah pelayanan kesehatan tidak terjadi pengeluaran biaya percuma untuk diagnosis dan pengobatan karena kesalahan dalam menetapkan seseorang menderita anemia. ${ }^{14}$

Seseorang yang ditetapkan positif pada pemeriksaan namun pada kenyataannya tidak menderita suatu penyakit akan berdampak pada sisi psikologinya. Dampak kesalahan tersebut akan membuat seseorang mengalami ketakutan, bahkan dapat dianggap cacad seumur hidup dan susah mendapat pekerjaan. ${ }^{14}$

\section{4) Positif palsu pemeriksaan kadar hemoglobin menggunakan metode} $\mathrm{Hb}$ meter pada remaja putri di MAN 1 Wonosari

Berdasarkan hasil pemeriksaan kadar hemoglobin menggunakan metode $\mathrm{Hb}$ meter dengan standarisasi metode cyanmethemoglobine yang merupakan baku emas (gold standard) untuk menentukan seseorang menderita anemia, nilai negatif palsu yang diperoleh sebesar 54,54\%. Negatif palsu merupakan pelengkap dari nilai sensitivitas. Negatif palsu perlu untuk diketahui karena berhubungan dengan seseorang yang sebenarnya menderita suatu penyakit namun pada kenyataannya tes yang didapatkan negatif. Selain itu, perlunya negatif palsu diketahui untuk mencegah terjadinya penularan penyakit yang lebih meluas apabila orang tersebut menderita penyakit menular dan penyakitnya tersebut bertambah berat karena tidak diobati, bahkan dapat menimbulkan kematian karena kesalahan dalam penanganan. ${ }^{14} \mathrm{Di}$ samping itu ada penyakit seperti kanker hanya dapat disembuhkan dalam stadium dini, sehingga kegagalan dalam mendiagnosis stadium dini mengakibatkan penyakit tidak dapat diobati selama-lamanya. ${ }^{14}$

Sensitivitas dan spesifisitas adalah tingkat validitas yang digunakan untuk mengukur kemampuan suatu uji diagnostik dalam mendiagnosa suatu penyakit. Sensitivitas dan spesifisitas yang tinggi dari suatu uji diagnostik menunjukkan tingkat validitas yang tinggi dari suatu uji. Uji 
diagnostic laboratorium yang memiliki tingkat validitas yang tinggi sangat bermanfaat untuk mendeteksi atau mendiagnosa suatu penyakit dengan nilai keakuratan hasil uji yang tinggi dengan tingkat negatif dan positif palsu dari hasil uji yang rendah. Uji laboratorium yang memiliki tingkat sensitivitas dan spesifisitas yang tinggi juga dapat mempengaruhi kecepatan dalam menentukan suatu kebijakan terhadap masuknya suatu penyakit pada suatu wilayah tertentu. ${ }^{15}$

Uji diagnostik yang baik harus memberikan hasil yang sama apabila uji dilakukan terhadap subyek yang sama dan waktu yang sama. Uji diagnostik yang memberikan hasil positif atau negatif sering dipakai untuk menentukan prevalens penyakit, hal ini sangat penting karena berkaitan dengan kesehatan masyarakat dalam hal penentuan kebijakan, misalnya untuk keperluan intervensi dalam mencegah atau menanggulangi suatu penyakit yang banyak terdapat dalam masyarakat.

\section{Simpulan dan Saran}

\section{A. Simpulan}

Berdasarkan hasil analisis dan pembahasan mengenai validitas alat $\mathrm{Hb}$ meter di MAN 1 Wonosari, Gunungkidul dapat disimpulkan bahwa:

1) Sensitivitas yang diperoleh dalam penelitian ini sebesar $45,45 \%$, yang artinya alat uji diagnostik ini memiliki sensitivitas yang kurang baik.

2) Spesifisitas yang diperoleh dalam penelitian ini sebesar $64,61 \%$, yang artinya alat uji diagnostik ini memiliki spesifisitas yang kurang baik.

3) Positif palsu yang diperoleh dalam penelitian ini sebesar $35,58 \%$, positif palsu merupakan pelengkap dari spesifisitas.

4) Positif palsu yang diperoleh dalam penelitian ini sebesar $54,54 \%$, negatif palsu merupakan pelengkap dari sensitivitas.

\section{B. Saran}

1. Bagi Dinas Kesehatan Kabupaten Gunungkidul

a. Diharapkan dapat digunakan sebagai acuan dan evaluasi dalam program penyediaan alat pemeriksaan kadar hemoglobin metode cyanmethemoglobine di puskesmas.

b. Tidak menggunakan metode $\mathrm{Hb}$ meter untuk uji diagnostik dalam menentukan seseorang menderita anemia.

\section{Bagi FKM UAD}

Menyebarluaskan informasi ke puskesmas mengenai kelemahan metode $\mathrm{Hb}$ meter untuk uji diagnostik, sehingga dokter yang ada di puskesmas tidak langsung mendiagnosa seseorang sebagai penderita anemia jika kadar hemoglobinnya rendah dan perlu dilakukannya pemeriksaan ulang dengan metode cyanmethemoglobine sebagai gold standard nya.

\section{Daftar Pustaka}

1. WHO, Worldwide prevalence of anaemia 2005-2008, WHO Global Database on Anaemia, www.who.int, diakses pada tanggal 23 April 2013, Yogyakarta, 2008.

2. Viveki, R., G., Halappanavar, A., B., Viveki, P., R., Halki, S., B., \& Maled, V., S., Prevalence of Anaemia and Its Epidemiological Determinants in Pregnant Women, Al Ameen J Med Sci, vol/no: 5(3), pp. 216-223, 2012.

3. Proverawati, Atikah, Anemia dan Anemia Kehamilan, Nuha Medika, Yogyakarta, pp. 1-2, 25-26, 2011. 
4. Tarwoto, Aryani, R., Nuraeni, A., Miradwiyana, B., Sumiati, Dinarti, Nurhaeni, H, Kesehatan Remaja Problem dan Solusinya, Salemba Medika, Jakarta, pp. 26, 2012.

5. Pearce, Evelyn, C., Anatomi dan Fisiologi Untuk Paramedis, PT Gramedia Pustaka Utama, Jakarta, pp. 160, 2009.

6. Gandasoebrata, P., Penuntun Laboratorium Klinik, Dian Rakyat, pp. 1-4, 7, 11, 2007.

7. Usman, Yuslely, validasi klasifikasi anemia pada balita dengan melihat kepucatan telapak tangan, Media Litbang Kesehatan, Vol/no: 13(1), pp. 15, 2003.

8. Azwar, S., Sikap Manusia Teori dan Penanggulangannya, Pustaka Pelajar, Yogyakarta, pp. 18, 2010.

9. Briawan, Dodik, Anemia Masalah Gizi pada Remaja Wanital, EGC, Jakarta, pp. 4, 2013.

10. Ernawati, Skrining Anemia Berdasarkan Keluhan Gejala Klinis pada Pekerja di Pabrik Kulit PT. Budi Makmur Jaya Murai Yogyakarta 2011, Skripsi, Universitas Ahmad Dahlan Yogyakarta, 2011.

11. Setiawati, Tusi, Perbedaan Hasil Pemeriksaan Kadar Hemoglobin dengan alat Spektrofotometer 4010 dan BC-2600 Auto Analizer Hematologi, Universitas Muhammadiyah Semarang, 2011.

12. Nugrahaeni, Dyah, K., Konsep Dasar Epidemiologi, Buku Kedokteran EGC, Jakarta. Hal 70, 2011.

13. Morton, Richard, F., Hebel, J., R., McCarter, R., J., Panduan Studi Epidemiologi dan Biostatistika, EGC, Jakarta, pp. 53, 2008.

14. Lapau, Buchari, Prinsip dan Metode Epidemiologi, Balai Penerbit FKUI, Jakarta, pp. 92-93, 2009.

15. Bogia, Steven, Y., Kardena, I Made, Sukada, I Made, Supartika, Ketut, E., Perbandingan Sensitivitas dan Spesifisitas Uji Pewarnaan Sellers' dan Fluorscent Antibody Technique (FAT) dalam Mendiagnosa Penyakit Rabies pada Anjing di Bali, Indonesia Medicus Veterinus, vol/no: 1(1), pp. 12-21, 2012. 
